\title{
NEUROLEPTIC PROPERTIES OF RG-TANNIN IN MICE AND RATS
}

\author{
${ }^{1}$ M. STAREC, ${ }^{2}$ J. ROSINA, ${ }^{3}$ R. SOVJAK, D. WAITZOVÁ \\ ${ }^{1}$ Department of Pharmacology ${ }^{2}$, Department of Biophysics, 3rd Medical Faculty, Charles University, Prague, \\ ${ }^{3}$ Veterinary Municipal Administration, Prague \\ Received March 14, 1996 \\ Accepted September 24, 1996
}

\begin{abstract}
Starec M., J. Rosina, R. Sovjak, D. Waitzová: Neuroleptic Properties of RG-tannin in Mice and Rats. Acta vet. Brno, 1996, 65: 209-212.

The purpose of the study was to examine the effect of RG-tannin, a new substance of plant origin (purified from rhizoma of Rhea raponticum) with assumed antipsychotic properties in two pharmacodynamic tests: 1 / in yawning behaviour induced with apomorphine or physostigmine in rats as an indicator of central antidopaminergic effects (in the case of apomorphine) and central anticholinergic effects (in the case of physostigmine), 2 / in Porsolt forced swimming test in mice (this test is sensitive to drugs activating or inhibiting central noradrenergic and dopaminergic mechanisms). RG-tannin in the dose of $50 \mathrm{mg} \cdot \mathrm{kg}^{-1}$ (but not $25 \mathrm{mg} . \mathrm{kg}^{-1}$ ) inhibited significantly yawning induced with apomorphine $\left(0.1 \mathrm{mg} \cdot \mathrm{kg}^{-1}\right)$, but failed to decrease yawning to a significant extent in rats treated with physostigmine $\left(0.075 \mathrm{mg} . \mathrm{kg}^{-1}\right)$. RG-tannin given intraperitoneally in mice in the dose of $25 \mathrm{mg} . \mathrm{kg}^{-1}$ and $50 \mathrm{mg} \cdot \mathrm{kg}^{-1}$ body weight increased statistically significantly the time of immobility in forced swimming test in comparison with mice treated only with saline.

All these findings indicate that RG-tannin has interesting neuroleptic properties, which could be useful also in veterinary medicine.
\end{abstract}

Yawning, Porsolt test, Rhea raponticum, rhizoma

Immobilization (restraint) induced by neuroleptics or combination of neuroleptics with analgesic drugs to induce neuroleptanalgesia is used for a variety of procedures in veterinary medicine (Vodrážka 1986; Geiser 1990; Dass and Sahay 1992). New neuroleptics with antistress and anxiolytic properties were found to have the positive effect for example in the treatment of sows suffering from post-weaning stress (Kyriakis 1990). Cox et al. (1989) showed that chlorpromazine inhibited diarrhoea, vomiting and increased survival in weaned piglets inoculated with combined infection of transmissible gastroenteritis virus and enterotoxigenic $E$. coli strain. However, the use of neuroleptic drugs is not without side effects, some of which may be serious (for example haemodynamic and thermoregulatory instabilities, etc). The search is therefore concentrated on the development of new perspective neuroleptics which would be safe and helpful in indications mentioned above.

We examined the effect of a new substance from plant origin, RG-tannin, a gallotanin purified from rhizoma of rhubarb (Tsumura company original literature; Yokozawa et al. 1991). It was found that this drug could have remarkable antipsychotic activities. In contrast to classical neuroleptics RG-tannin even in high doses did not potentiate the pentobarbital sleep time (unpublished data). Its positive effect on uraemic toxins was also established (Yokozawa 1991). In our previous study we showed that this compound increased hot plate reaction time alone and it potentiated the analgesic activity of morphine (Starec et al. 1988). In the present study we examined the effect of RG-tannin in two pharmacodynamic tests: 1 / in yawning behaviour induced with apomorphine or physostigmine in rats as an indicator of central antidopaminergic effects (in the case of apomorphine) and central anticholinergic effects (in the case of physostigmine), $2 /$ in Porsolt forced swimming test in mice (this test is sensitive to drugs activating or inhibiting central noradrenergic and dopaminergic mechanisms). 


\section{Materials and Methods}

\section{Yawning behaviour}

Male Wistar rats weighing 200-250 g were used in this experiment. They were maintained four per cage at least one week before testing with free access to food and water. One day prior to the experiment they were put into individual cages. Food and water were withdrawn during the behavioural observation. The number of yauns was counted for 60 minutes by direct observation immediately after injection of apomorphine $\left(0.1 \mathrm{mg} \cdot \mathrm{kg}^{-1}\right)$ or physostigmine $\left(0.075 \mathrm{mg} \cdot \mathrm{kg}^{-1}\right) .30$ minutes before they were pretreated with saline (controls). RG-tannin (Tsumura, Japan) in the doses of 25 and $50 \mathrm{mg}^{-\mathrm{kg}^{-1}}$ or haloperidol (inj. Richter, Hungary) in the dose of $0.02 \mathrm{mg} \cdot \mathrm{kg}^{-1}$. All drugs were injected subcutaneously (diluted with saline) in the volume of $0.8-1.2 \mathrm{ml}$. No more than four rats were observed simultaneously. The mean number of yawns of each group was compared to that of the respective control group by use of Student's t-test. 11 or 12 rats were included in each experimental groups.

\section{Forced swimming test}

Male, white ICR strain mice weighing 25-30 g were used. The mice were kept in cages per 10 animals having free access to food and water. The used forced swimming test was a modefication of that described by Porsolt et al. (1977). Mice were forced to swim for 6 min inside a vertical cylinder of transparent plastic with the diameter $20 \mathrm{~cm}$ filled with water $32{ }^{\circ} \mathrm{C}$ to $15 \mathrm{~cm}$ height from which they could not escape. The total duration of immobility during the last $3 \mathrm{~min}$ was recorded. Mice were judged to be immobile whenever they remained floating in the water, in an upright position, making only very small movements necessary to kepp their head above water.

RG-tannin (Tsumura, Japan) in the dose $5 \mathrm{mg} \cdot \mathrm{kg}^{-1}$, $25 \mathrm{mg} \cdot \mathrm{kg}^{-1}$ and $50 \mathrm{mg} \cdot \mathrm{kg}^{-1}$, and for comparison haloperidol (inj. Richter, Hungary) and droperidol (inj. Richter, Hungary) $2 \mathrm{mg} \cdot \mathrm{kg}^{-1} 0.2 \mathrm{mg} \cdot \mathrm{kg}^{-1}$ and 2<smiles>Cc1ccc([C@H]2Oc3cc(O)c([C@@H]4c5c(O)cc(O)c([C@H]6C7=CC=C(O)C(O)=C[C@H](O)[C@@H]7Oc7cc(O)cc(O)c76)c5O[C@H](c5ccc(O)c(O)c5)[C@H]4O)c(O)c3C[C@H]2O)cc1O</smiles>

Fig. 1

Structural formula of RG-tannin $\mathrm{mg} . \mathrm{kg}^{-1}$ were used. The chemical structure of RC-tannin is shown in Fig. 1. All drugs were given intraperitoneally diluted with saline to the volume of 0.8 to $1.2 \mathrm{ml} 15$ minutes before placing them into the water. Control groups were injected with saline only. The mean duration of immobility in each group was compared to that of the respective control group by use of Student's t-test. 12 animals were included in each group.

\section{Results}

\section{Yawning behaviour induced with apomorphine}

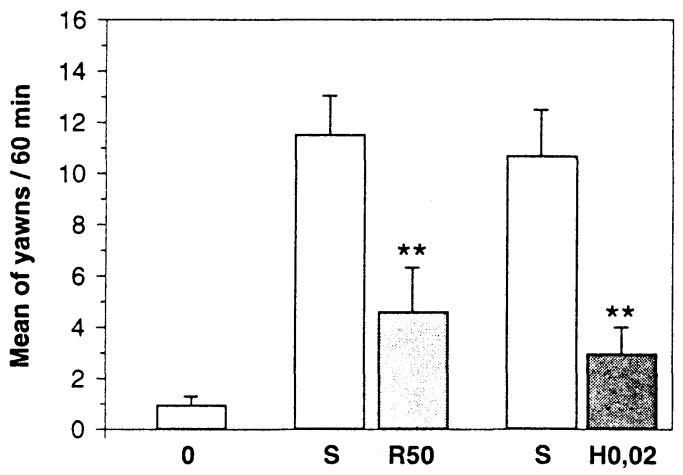

RG-tannin in the dose of 50 mg. $\mathrm{kg}^{-1}$ (but not $25 \mathrm{mg} \cdot \mathrm{kg}^{-1}$ ) inhibited significantly yawning

Fig. 2

Effect of RG-tannin on yawning behaviour induced with apomorphine $\mathrm{O}=$ saline only, $\mathrm{n}=11$

$\mathrm{S}=$ saline + apomorphine (control group), $\mathrm{n}=11$

$\mathrm{R} 50=$ RG-(tannin $\left(50 \quad \mathrm{mg} \cdot \mathrm{kg}^{-1}\right)$

+ apomorphine, $\mathrm{n}=11$

$\mathrm{H} 0.02=$ haloperidol $\left(0.02 \mathrm{mg} \cdot \mathrm{kg}^{-1}\right)$ + apomorphine, $\mathrm{n}=12$

$* *=p<0.01$ compared with control group

shown are means of yawns recorded during $60 \mathrm{~min}+$ SEM 


\section{Porsolt fest - time of immobility}

(forced swimming in $32{ }^{\circ} \mathrm{C}$ warm water)

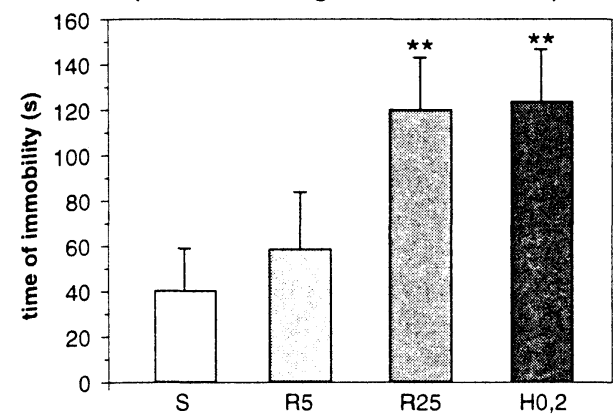

Fig. 3

Effect of RG-tannin in Porsolt's forced swimming test $\mathrm{S}=$ saline (control group), $\mathrm{n}=12$

$\mathrm{R} 5=\mathrm{RG}$-tannin $\left(5 \mathrm{mg} \cdot \mathrm{kg}^{-1}\right), \mathrm{n}=12$

R25 = RG-tannin $\left(25 \mathrm{mg} \cdot \mathrm{kg}^{-1}\right), \mathrm{N}=12$

$\mathrm{H} 0.2$ = haloperidol $\left(0.2 \mathrm{mg} \cdot \mathrm{kg}^{-1}\right), \mathrm{n}=12$

$* *=p<0.01$ compared with control group

shown are mean times of immobility during

3 minutes observation and SEM

induced with apomorphine. Haloperidol in the dose of 0.02 $\mathrm{mg} \cdot \mathrm{kg}^{-1}$ which we used for comparison with RG-tannin diminished yawning to $23 \%$ while RG-tannin decreased yawning to $41 \%$ when compared with their control groups. Selected values are presented on Fig. 2. RG-tannin even in the dose of $50 \mathrm{mg} \cdot \mathrm{kg}^{-1}$ failed to decrease yawning to a significant extent in rats treated with physostigmine (data not shown).

RG-tannin given intraperitoneally already in the dose of $25 \mathrm{mg} \cdot \mathrm{kg}^{-1}$ of body weight increased significantly the time of immobility in the forced swimming test in comparison with mice treated only with saline. The dose of $25 \mathrm{mg} \cdot \mathrm{kg}^{-1}$ seemed to be equipotent to $0.2 \quad \mathrm{mg} \cdot \mathrm{kg}^{-1}$ of haloperidol. RG-tannin in the dose of $5 \mathrm{mg} \cdot \mathrm{kg}^{-1}$ was without any effect when compared to the control group (Fig. 3). Haloperidol in the dose of $2 \mathrm{mg} \cdot \mathrm{kg}^{-1}$ had a stronger effect than droperidol in the dose of $2 \mathrm{mg} \cdot \mathrm{kg}^{-1}$ (times of immobilities were $142.37 \pm 30.42 \mathrm{~s}$., $108.55 \pm 32.71 \mathrm{~s}$, respectively) and than RG-tannin in the dose of $50 \mathrm{mg} \cdot \mathrm{kg}^{-1}(111.25 \pm$ $36.73 \mathrm{~s})$.

\section{Discussion}

RG-tannin inhibited yawning induced with a dopaminergic antagonist apomorphine but failed to decrease yawning in rats treated with an inhibitor of acetylcholinesterase, physostigmine. This suggests that the new substance of plant origin has antidopaminergic activity and that its anticholinergic components are less important. RG-tannin also significantly increased the time of immobility in the forced swimming test which is typical for neuroleptics in contrast to antidepressive drugs. This test is reported to be sensitive to drugs activating or reducing noradrenergic and dopaminergic mechanisms in the brain but relatively insensitive to serotoninergic mechanisms (Porsolt et al 1997. 1978; B orsini et al. 1981). The drugs, which block dopaminergic receptors, as for example haloperidol, chlorpromazine or primozide, increased the duration of immobility in Porsolt's swimming test (Porsolt et al. 1977, 1979). The comparable effect of RG-tannin with that of haloperidol in forced swimming test again supports antidopaminergic effect od RG-tannin. In our previous study we demonstrated that RG-tannin itself had an antinociceptive effect on hot plate (even in the dose of $1 \mathrm{mg} \cdot \mathrm{kg}^{-1}$ ) and in tail-flick test (in the dose of $50 \mathrm{mg} \cdot \mathrm{kg}^{-1}$ ). It also could have potentiated the analgesic activity of morphine on hot plate test ( $\mathrm{S}$ tarec et al. 1988). All these findings let us to the assumption that RG-tannin has neuroleptic properties, which could be useful in combination with analgesic to produce neroleptanalgesia and also in other areas of veterinary medicine. However, further experiments are needed to clarify the exact mechanisms of action of this compound. 


\section{Neuroleptické účinky RG-tanninu u myší a potkanů}

Sledovali jsme efekt RG-tanninu, nové látky rostlinného původu (purifikované $\mathrm{z}$ kořene Rhea raponticum) s předpokládanými antipsychotickými vlastnostmi ve dvou farmakodynamických testech: 1/ $\mathrm{v}$ testu zívání indukovaného apomorfinem nebo fysostigminem u potkanů jako ukazatele centrálních antidopaminergních účinků (v případě apomorfinu) a centrálních auticholineregních účinků $\mathrm{v}$ př́padě fysostigminu), 2/ v Porsoltově nuceného plavání u myší (test je sensitivní na látky, které aktivují nebo inhibují centrální noradrenergní a dopaminergní mechanismy).

RG-tannin v dávce $50 \mathrm{mg} / \mathrm{kg}$ (ne však v dávce $25 \mathrm{mg} / \mathrm{kg}$ ) signifikantně inhiboval u potkanů zívání vyvolané apomorfinem $(0.1 \mathrm{mg} / \mathrm{kg})$, ale neměl efekt na zívání indukované fysostigminem $(0.075 \mathrm{mg} / \mathrm{kg})$. V testu nuceného plavání RG-tannin podaný myším v dávce 25 a $50 \mathrm{mg} / \mathrm{kg}$ tělesné hmotnosti statisticky významně zvýšil dobu imobility ve srovnání se skupinou myší, kterým byl aplikován jen fyziologický roztok.

Všechna tato ujištění ukazují, že RG-tannin má zajímavé neuroleptické účinky, které by mohly být užitečné také ve veterinární medicíně.

\section{References}

BORSINI, F.- BENDOTTI, G.- VELKOW, V.- RECH, R.- SAMANIN, R. 1981: Immobility test: effect of 5hydroxytryptaminergic drugs and role of catecholamines in the activity of some antidepressants. J. Pharm. Pharmac. 33: 33-37

COX, E.- COOLS, V.- HOUVENAGHEL, A. 1989: Effect of antisecretory drugs on experimentally induced weanling diarrhoea in piglets. Vet. Res. Commun. 13: 159-70

DASS, D. D.- SAHAY, P. N. 1992: Haemodynamic responses following meperidine and promazine induced neuroleptanalgesia in calves. Zbl. Vet. Med. 39: 38-42

GEISER, D. R. 1990: Chemical restraint and analgesia in the horse. Vet. Clin. Notrh. Am. Equine Pract. 6: $495-512$

KYRIAKIS, S. C.- MARTINSSON, K.-OLSSON, N. G.- BJORK, A. 1990: Thin sow syndrom (TSS): the effect of amperozide. Br. Vet. J. 146: 436-476

PORSOLT, R.- LE PICHON, M.-JALFRE, M. 1977: Depression: a new animal model sensitive to antidepressant treatments. Nature 266: 730-732

PORSOLT, R. D.-BERTIN, A.- JALFRE, M. 1978: Behavioural despair in rats and mice: strain differences and the effects of imipramine. Eur. J. Pharmacol. 51: 291-294

PORSOLT, R. D.- BERTIN, A.- BLAVET, N.- JALFRE, M. 1979: Immobility induced by forced swimming in rats: effect of agents which modify central catecholamine and serotonin activity. Eur. J. Pharmacol. 57: 201-210

STAREC, M.- WAITZOVÁ, D.-ELIS, J. 1988: Hodnocení analgetického účinku RG-tannin metodou horká deska a tail.flick u myší. Čs. Farmacie, 7: 319-321

VODRÁŽKKA. J. 1986: Veterinárska medicína a farmakológia. Osveta, Martin

YOKOZAWA, T.-FUJIOKA, K.-OURA, H.-NONAKA, G.- NISHIOKA, I. 1991: Effect of rhubarb tannins on uraemic toxins. Nephron. 58: 155-160

Address for correspondence:

MUDr. M. Starec. CSc.

Department of Pharmacology

3rd Medical Faculty, Charles University

Ruská 87

CZ-10000 Praha 10

Czech Republic 